\title{
HUNGARIAN VOWEL QUANTITY NEUTRALISATION AS A POTENTIAL SOCIAL MARKER*
}

\author{
KATALIN MÁDY \\ Institut für Phonetik und Sprachverarbeitung \\ Ludwig-Maximilians-Universität München \\ Schellingstr. 3 \\ D-80799 München \\ Germany \\ mady@phonetik.uni-muenchen.de
}

\begin{abstract}
Hungarian is a language with distinctive vowel quantity, but it seems that quantity discrimination in acoustic and perceptual terms is less robust for high vowels than for low ones. In this paper, we argue that the unstable behaviour of high vowels could refer to a sound change from below in Labov's terminology. Due to our results, quantity loss was observed both for high and partly also for mid vowels, especially in unstressed position. The extent of quantity neutralisation showed an interaction with speech style, linguistic attitude, and partly also social status, but not with gender, age-dependent occupation or regional affiliation.
\end{abstract}

Keywords: vowel quantity, Hungarian, sociophonetics, sound change, change from below

\section{Introduction}

\subsection{Linguistic markers}

An important feature of language communities is the knowledge they share about linguistic elements that refer to speaker characteristics. Laver and Trudgill (1979) define three categories of markers, based on the typology of Abercrombie (1967):

* I would like to thank to Klára Vicsi and her staff, especially György Szaszák, Dávid Sztahó, and Szabolcs Tóth, for the possibility to use their laboratory. This work is part of the excellence project Speaker characteristics and language society supported by the German Research Council. 
- social markers that mark social characteristics (social status, educational status, occupation, regional affiliation, etc.);

- physical markers that refer to physical characteristics (age, gender, state of health, etc.);

- psychological markers that are connected to the affective state and personality of the speaker.

Linguistic, and especially social, markers have played a crucial role in sociolinguistic research since Labov, and they have been extensively used in investigating and describing sound change. Labov (1994) describes two basic sound change processes: change from above is normally introduced by the dominant social class of a society, the process appears first in careful speech style, and speakers are conscious about the change. Change from below, on the other hand, reflects internal linguistic factors and can be introduced by any social class (but most typically by the lower middle class or upper working class rather than the dominant class). Speakers are typically unconscious about sound change from below, but the phenomenon can reach the threshold of consciousness and become a so-called stereotype (ibid.). Sound change is not only dependent on social but also on physical markers such as gender or age (see, e.g., Harrington et al. 2008 on age-dependent /u/-fronting in British, and Milroy-Gordon 2003 on gender, age, and social status).

In this paper, we will describe a phenomenon in Hungarian that might refer to sound change that is either still in progress or has taken place recently, namely quantity neutralisation in high and partly in mid vowels. First, we will give a short description of an asymmetry in the sound system that might have given rise to the change. Then we will turn to former experiments that have provided evidence that the phenomenon has the status of a social marker; and finally, we will investigate whether the scope of the linguistic marker has become larger during the past 50 years.

\subsection{Vowel quantity in Hungarian}

Standard Hungarian contains 14 vowels: /i, is, y, y: u, u:, $\varnothing, \varnothing:$, o, o: $\varepsilon$, e: $\mathrm{p}, \mathrm{a}: /$. The first ten vowels can be arranged into five, phonetically similar quantity pairs. However, there are two competing views on the relationship between $/ \varepsilon /$ and /e:/ on the one hand and /p/ and /a:/ on the other. Phonetically based descriptions would argue that since these 
vowels are less similar to each other, i.e., they are distinguished by additional articulatory characteristics, there is no reason to regard them as two members of one single quantity pair, but rather as independent vowels. (For details on the articulatory distinctions across these vowels see Mády 2008.)

On the other hand, phonological descriptions focus on the fact that some rules which trigger the alternation of long and short vowels also apply to / $\varepsilon /-/$ e: / and /o/-/a:/ (Siptár-Törkenczy 2000). One such rule is Final Stem Vowel Shortening: in certain stems, a long vowel is replaced by its short counterpart if a suffix is added to the stem, e.g., kút /ku:t/ 'well' - kutak /kutok/ 'wells', kéz /ke:z/ 'hand' - kezel /kezel/ 'to handle', sár / Jarr/ 'mud' - sarat / jprot/ 'mud-acc'. Another example is Internal Stem Vowel Shortening (e.g., aktív / pktirv/ 'active' - aktivál / pktiva:l/ 'to activate'. (See Siptár-Törkenczy 2000 for a detailed description of these rules.)

It is noteworthy that Hungarian orthography that is based on morphophonological principles reflects the concept of seven short-long vowel pairs by marking long vowels by an acute accent: $u / \mathrm{u} /-\dot{u} / \mathrm{u} /, \ddot{o} / \varnothing /-$ $o$ / $\varnothing: /, a / \mathrm{p} /-a ́$ /a:/. While orthography obviously cannot be used as an argument in the debate described above, it might be the case that the notation has an impact on the phonological consciousness of the speakers.

The different treatment of long and short vowel pairs in the phonetic and phonological traditions are accounted for in a framework presented by Siptár-Törkenczy (2000). In this model, phonological vowel pairs are divided into three categories based on their distribution and functional load within the phonological system:

- High vowel pairs $/ \mathbf{i}-\mathbf{i}: /, / \mathbf{y}-\mathbf{y}: /, / \mathbf{u}-\mathbf{u}: /:$ minimal functional load of quantity distinction in lexical units + limited occurrence of long vowels in most positions, at least in Educated Colloquial Hungarian.

- Mid vowel pairs /o - $:$ : /, /o- o:/: the number of quantity-based minimal pairs is not very high + only long vowels occur in word-final position.

- Mixed $^{1}$ vowel pairs $/ \boldsymbol{\varepsilon}-\mathbf{e}: /, / \mathbf{p}-\mathbf{a} /$ : additional morphophonological rules for quantity alternation, free distribution of short and long vowels + a large number of quantity-based minimal pairs.

${ }^{1}$ Siptár and Törkenczy (2000) use the term low for this category since in their generative framework /e:/ can be described as an underlyingly low vowel. In our surface-oriented study, we will stick to phonetic characteristics and prefer the less theory-bound term mixed for this class. 
The phonetic validity of the continuum from high over mid to mixed vowel pairs is often complemented by the assumption that the quality distinction (centralisation) is small for high and somewhat larger for mid vowels (first described by Magdics 1965). This raises the question whether mid vowels can be characterised by an intermediate state between high vowels that make little use of a quality distinction and low vowels for which the distinction stretches over an entire vowel category.

The findings of Kovács (2002) support this assumption. In her lexical choice perception experiment, participants relied on quality cues for mid vowels to a higher extent than for high ones (the experiment did not include low vowels). The distinction of short and long vowels by their duration follows the same pattern: Mády and Reichel (2007) showed that there was a considerable durational overlap between short and long high vowels (i.e., short vowels were not necessarily shorter than long ones, even in identical carrier sentences), while durations of $/ \mathrm{p} /$ and $/ \mathrm{a}$ / were clearly distinct. Mid vowels and the mixed pair $/ \varepsilon /$ and $/ \mathrm{e} / \mathrm{showed}$ an intermediate behaviour.

The unstable durational distinction of high vowels is further accompanied by the lack of a reliable quality distinction. As we argued in Mády et al. (2008), long and short high vowels share identical articulatory target configurations, but not mid and mixed vowel pairs.

Before turning to sociophonetically related questions, we would like to raise a general issue. If a quantity distinction is accompanied by further features such as tenseness or vowel height, it would be unsurprising if the durational distinction was neutralised, while the vowel distinction would be maintained by alternative cues such as vowel quality. This is the case in Czech, another quantity language, in which front high vowels are realised as /I/ and /is/, i.e., centralisation is an additional cue. As shown by Podlipský et al. (2009), the spectral characteristics of these vowels are becoming more important in modern Czech, while the durational distinction is becoming weaker.

We cannot provide an answer why the vowel systems of Czech and Hungarian show a different developmental pattern. However, it is important to point out that there are regional varieties of Hungarian in which long high vowels are absent (see below in 3.1.2). Since a vowel system with a neutralised distinction already exists in this language, it might facilitate analogous sound change processes. A more general overview of this issue would be highly desirable. 


\subsection{Neutralisation of the quantity distinction for high vowels}

It seems that the quantity distinction of high vowels has poor manifestation in terms of duration or quality in modern Hungarian. This fact is also reflected in varieties: first, dialects vary to a high extent with regard to their use of short and long high vowels: while Western dialects often lack long /u:/ and /y:/ (and sometimes also /i:/) entirely, these sounds are overrepresented in Eastern dialects (Western hus vs. standard hús 'meat', Eastern sima vs. standard sima 'smooth, plain'). Futhermore, there is often a gap between orthography and the - widely accepted - Educated Colloquial Hungarian, resulting mostly in shortening, but sometimes in lengthening compared to the standard form (colloquial szines vs. orthographic szines 'colourful', colloquial túrista vs. orthographic turista 'tourist'; see Siptár-Törkenczy 2000 for more examples.)

While the unstable character of high vowel quantity is obvious for most experts and many naïve speakers of Hungarian, only few researchers have attempted to reveal the nature of the neutralisation process in a sociophonetic framework. Magdics (1960) described vowels that are often shortened in colloquial speech as labile vowels. She compared them to stable short and long vowels by means of durational measurements for speakers of four generations. She found that labile long vowels (typically unstressed high or mid vowels) were realised with durations close to those of stable short vowels, but with considerably larger durational variation. Magdics' study revealed a sound change in progress at the time of the study: speakers who were older than 70 years did not neutralise quantity in these words, speakers younger than 30 consistently did, while speakers' durations in the middle groups varied between these poles.

Another study was carried out by Kassai (1991) who compared vowel realisations by classifying them as short or long auditorily. The study included two groups: students of so-called vocational schools ${ }^{2}$ who are typically located lower on the social scale, and secondary school teachers with higher status. (In other words, young participants of lower status were compared to older participants with higher status.) This study emphasises that variation is dependent on educational status and style: while students used short high vowels where orthography suggests a long

${ }^{2}$ This educational form in Hungary (szakmunkásképző) is often preferred by young people who wish to be trained in some skill or trade after primary school, i.e., after the 8 th class. The degree from this school type does not provide direct access to university. 
one in all speech styles, teachers relied on the norm in formal style and neutralised only in colloquial speech.

Both studies concentrated on lexical units that include a labile vowel quantity, i.e., whose colloquial pronunciation differs from standard. The following questions arise: (1) Is there a tendency to neutralise high vowel durations in stable syllables in the present language usage? (2) Is the continuum from high via mid to mixed vowel pairs present in different speaking styles? (3) Is there an interaction between social class, agedependent occupation, gender or regional affiliation and the degree of quantity distinction? (4) Do speakers use quantity neutralisation as a social marker depending on their attitude to the language?

It is important to note that we do not expect answer all these questions in the present pilot study. Our goal is rather to explore general tendencies that might encourage future research based on a larger database.

\section{Materials and methods}

\subsection{Speakers}

Participants were recorded in a sound-treated room at the Laboratory of Speech Acoustics, Budapest University of Technology and Economics (25 speakers). A test recording session took place in an anechoic room at the Institute of Phonetics and Speech Processing, University of Munich (2 speakers). Audio signal was recorded by the SpeechRecorder software ${ }^{3}$ at a sampling rate of $44.1 \mathrm{kHz}$ to a $\mathrm{PC}$ via an external analogue-digital converter.

All speakers were native speakers of Hungarian and had spent most of their lives in a Hungarian-speaking environment. ${ }^{4}$ No speaker reported speech or hearing disabilities.

Participants were asked to fill in a questionnaire requesting the following data about their mother, father and themselves: age, sex, residence

${ }^{3}$ SpeechRecorder is a free software, developed by Christoph Draxler and Klaus Jänsch at the Institute of Phonetics and Speech Processing, University of Munich. Download and documentation: http://www.phonetik.uni-muenchen.de/ forschung/Bas/software/speechrecorder/

4 This was also true for the two Munich speakers: one of them was a visiting student from Hungary, the other participant was raised in Hungary and is a double resident in Germany and Hungary. 
during childhood, highest educational degree, actual profession, and dialect usage. They were also asked about their competence in foreign languages and longer stays-abroad. In addition, several statements about attitude towards language usage were given which could be accepted or refused by subjects as describing them correctly.

As participant acquisition did not follow a systematic pattern with regard to social criteria, the distribution of subjects along with the answers collected in the questionnaire will be described below in 3.1.

\subsection{Speech material}

Target syllables had the structure CVC, preceded and followed by a vowel segment. Target vowels were the high vowels $/ \mathrm{u} /$ and $/ \mathrm{u} / \mathrm{m}$, mid $/ \mathrm{o} /$ and /o:/, low $/ \mathrm{p} /$ and $/ \mathrm{a}: /$. In order to minimise coarticulatory backing or rounding effects and to facilitate segmentation, target vowels were flanked by /t/ where possible, alternatively by other alveolar obstruents such as $/ \mathrm{s} /$ or $/ \mathrm{d} /$.

Carrier words occurred in a potentially accentable sentence position and were one or three syllables long. Stressed target syllables were located on the first syllable of the carrier word (N. B. Hungarian has fixed stress on the first syllable), unstressed ones on the third syllable. The first set contained short sentences with six to eight syllables, the second set included sentences with approximately seventeen syllables. The first set was read with careful, the second with neutral pronunciation. ${ }^{5}$ Words with final target syllables were embedded in non-final phrase position in order to minimise the possibility that a phrase boundary was produced after them; e.g., Anitát is 'Anita-acc also', vonatút alatt 'train journey during?

Comparability between short and long vowels can be best achieved if all other circumstances (prosodic structure, environment, etc.) are kept identical throughout the sentences. Therefore, phonetic studies often rely on pseudowords with identical CV structures and identical carrier sentences. While the advantages of this technique are obvious for many kinds of investigations, sociophonetic research is interested in linguistic behaviour and thus needs natural or close-to-natural speech material. For this reason, only real words of Hungarian embedded in meaningful (and not identical) sentences were used in this experiment.

${ }^{5}$ The reason why sentence length varied is explained in Mády et al. (2008). 
Target words were non-compound nouns or verbs of Hungarian (except for unstressed /u:/, see below). Words were monomorphemic (e.g., tud 'he/she knows', tataroz 'he/she renovates'), or they contained a suffix for the accusative, - $(V) t$ (e.g., szót 'word-acc', totemet 'totem-acc'). In colloquial speech, unstressed / $\mathrm{u}$ : is often produced as a short vowel (as a labile vowel according to Magdics 1960), but only in non-compound words. Therefore the compound vonatút 'train journey' with a stable /u:/ was chosen as a carrier word for unstressed /u:/.

Thus, the sentence set included 18 target words combined of 3 vowel categories $\times 2$ quantities $\times 2$ word lengths $\times 2$ stress levels (minus unstressed vowels in monosyllabic words which is not a meaningful category), embedded in short and long sentences. All sentences were repeated five times, in randomised blocks (sentence length did not vary within a block). The total number of tokens was $4617 .^{6}$

It was not always possible to find a meaningful Hungarian word with the structure $/ \mathrm{tVt} /$ in the desired position. If the vowel was flanked by consonants other than $/ \mathrm{t} /$, durations were corrected according to intrinsic durations listed in Magdics (1966) or according to our own measurements in previous studies: the intrinsic duration of the vowel $\mathrm{V}$ in a/t_t/ sequence was divided by the intrinsic duration of the vowel in the sequence in question (e.g., /d_t/). Vowel durations in sequences other than /tVt/ were then multiplied by this ratio.

\subsection{Methods}

Further analysis was based on manual duration segmentations in Praat. Two kinds of measurements were used in the analysis: (1) the ratio of the mean duration of corresponding short and long vowels (ratio of mean durations, MeanR), and (2) the durational overlap between the shortest long vowel and the longest short vowel within the same vowel pair (durational overlap, DurOL). According to the methodology, the latter is a more sensitive measure of neutralisation, while the former is more robust against outliers.

Both indices were applied to long and short equivalents in otherwise identical conditions (i.e., all other independent variables being the

${ }^{6}$ Two speakers only produced two repetitions of the tokens due to lack of their spare time; besides, one repetition of one target sentence was accidentally missing from the recording script. 
same). Thus, /o/ and /o:/ were compared in each condition separately: for example, durations of the vowel in SZOT / sot/ 'acronym for National Confederation of Trade Unions (NCTU)' in monosyllabic words in the sentence Ő a SZOT elnöke 'he/she is the president of NCTU' were compared to durations of the vowel in szót /so:t/ 'word-acc' in the sentence Érti a szót ő is 'He/she understands the word, too.', for each speaker, respectively. This resulted in 6 conditions for each vowel pair (high, mid, and low) and totalled thus in 18 indices per speaker.

The ratio of mean durations (MeanR) was calculated as follows: the mean duration of 5 repetitions of the short vowels was divided by the mean durations of the corresponding long vowels (within the same condition). When short vowels were produced with shorter mean durations than their long equivalents, the ratio was smaller than 1 . The closer the ratio was to 1 , the stronger the neutralisation tendency.

In addition to mean durations, we wanted to know whether all vowels within a quantity pair were distinguished by duration. This was quantified by the amount of durational overlap (DurOL): the longest duration of short vowels was subtracted from the shortest duration of long vowels within the same condition. Since the absolute difference alone was dependent on the speech rate of the individual speaker and the intrinsic duration of the vowels (low vowels are longer in Hungarian than high ones, like in most languages), the absolute value of the durational overlap was divided by the longest occurence of the vowel through all conditions by the speaker (no matter whether the longest realisation was a phonologically short or long vowel). If the index of the durational overlap was negative, all short vowels were shorter than their long counterpart, and an index greater or equal to 0 referred to neutralisation in at least one case.

\section{Results}

\subsection{Distribution through social factors}

As mentioned above, participant selection did not follow a representative pattern, since our intention was to investigate as many tendencies as possible. Thus, sociological categories were merged to larger categories. The grouping of subjects and the distribution according to these categories is described below. 


\subsubsection{Occupation and gender}

The youngest participant was 18, the oldest 63 years old (mean 30.8 years, SD 14.8 years). Following Milroy-Gordon (2003), the analysis was based on the type of occupation rather than on age in years or decades: 15 participants were still in education (secondary school or university), 10 subjects had been employed and 2 were retired. Both pensioners had been employed until recently prior to the study (and were younger than two other participants who still worked regularly), therefore they were included in the employed group. Mean age in the students' group was 20.8 years (range from 18 to 23 years), in the employees' group 43.3 years (range from 27 to 63 years).

14 participants were female, 6 of whom were students, while there were 9 male students. Thus, male employees were the smallest group in the sample (4 subjects).

\subsubsection{Regional affiliation}

There were few speakers who declared themselves or their parents speakers of a regional dialect. Some participants with lower education were uncertain about dialect usage in their families, others, especially subjects with a background in linguistics, tended to attribute dialect usage to themselves or their parents whereas this possibly only meant a slight dialectal influence in standard language usage.

Following the focus of this study on vowel quantity distinction, regions were classified according to the criterion whether their dialects maintain a quantity distinction for high vowels, as described by Kálmán (1989). The 10 subjects from the dialect regions dunántúli and nyugati in which vowel quantity for high vowels is likely to be neutralised were classified as Western Hungarian speakers. The second group consisted of 9 speakers from Southern and North-East Hungary and Transylvania where the quantity distinction is mostly maintained in dialects or at least, no systematic shortening of long vowels can be observed. As the capital cannot be attached to any of the traditional dialect regions, a third category was established for the remaining 8 speakers who were born and raised in Budapest.

\subsubsection{Social status}

Several indexation methods for social status have been used in the sociolinguistic tradition. While Labov favoured a technique based on the 
subject's father's occupation, we chose to follow another way, for two reasons. First, it is hardly possible to create a scale of professions along a single criterion in post-communist countries like Hungary where there is often a gap between educational status and income: state employees like school and university teachers or doctors often earn below average-but there is no reason to expect that their language usage would reveal a lower social status than that of employees in private companies with the same education. Second, the social status of Central-Eastern European families is not defined by the father's status alone, as the huge majority of women are also employed. Thus, there is no reason to include the father's but not the mother's occupation in the indexation method.

For this reason we decided to rely on the educational status of the participants and their parents. ${ }^{7}$ The following scheme was used: 3 scores: academic degree (from some institution of higher education, Hungarian egyetem or föiskola), 2 scores: secondary school graduation (Hungarian érettségi), 1 score: training in a trade (Hungarian szakmunkás), o score: 8 or less classes in primary school (Hungarian általános iskola). Thus, the scale ranged from 0 to 9 , where the individual scores cumulated the education scores of the subject and his/her two parents. University students were given 3 scores in order to avoid a bias towards lower social status in the students' group.

The largest group of 13 participants had an index of 9 , seven subjects scored 5 or less, and seven ranked between these two groups.

\subsubsection{Attitude}

Two statements out of five were used for the analysis of attitude towards careful speech:

1: I always try to maintain a careful pronunciation.

2: I think that a too exact pronunciation is artificial and does not fit to everyday speech.

Participants who felt that statement 1 but not statement 2 applied to them were attached to the category positive attitude towards careful pronunciation. Participants who had marked the second statement but not

7 This method was problematic if participants had little or no contact to their father or mother. In one case when this fact was known to the experimenter, data were provided about the grandmother instead of the mother - other similar cases may have stayed unrevealed. 
the first belonged to the group with negative attitude, and the remaining speakers were described as neutral. 6 speakers were characterised as having a positive, 10 as having a negative, and 11 as having a neutral attitude.

It cannot be excluded that participants' choice of statements had an influence on their linguistic behaviour during the recordings. However, the importance of this question is secondary for our analysis. Even if speakers deliberately used strategies to mark their attitude by their speech, their use of a higher or smaller amount of neutralisation is informative by itself.

\subsection{Quantity distinction by duration}

The analysis was based on repeated measures ANOVA where appropriate. If samples were not normally distributed and/or homogeneity of variances was not given, non-parametric Kruskal-Wallis (H-) tests were performed. For post-hoc tests, Bonferronis correction was applied to the resulting $\mathrm{p}$-values. The term significant refers to $p \leq 0.05$, highly significant to $p \leq 0.01$.

\subsubsection{Style/length}

As described in $\mathbf{2 . 2}$, the data set included short sentences with careful pronunciation and long sentences with normal (=neutral) pronunciation. Both MeanR and DurOL reflected a tendency towards quantity neutralisation in neutral, i.e., casual, speech style. Repeated measures ANOVA revealed a highly significant interaction for the within-subject factors speech style and vowel category (MeanR: $D F=2, F=14.487, p \leq 0.001$, DurOL: $D F=2, F=6.2031, p=0.0038)$. In accordance with our previous studies (Mády-Reichel 2007; Mády et al. 2008), the most consistent quantity distinction in terms of duration was found for /p/ and /a:/ (Figure 1), but this difference only reached significance in casual speech style: MeanR for /a/ was significantly lower than for $/ \mathrm{u} /(D F=1, F=13.619$, $p=0.015645),{ }^{8}$ DurOL for $/ \mathrm{a} /$ significantly lower than for $/ \mathrm{o} /$ and $/ \mathrm{u} /$ $(/ \mathrm{o} /: D F=1, F=18.873, p=0.0028, / \mathrm{u} /: D F=1, F=21.51$, $p \leq 0.001)$.

${ }^{8}$ All p-values are given after Bonferroni correction. From this point onwards, /a/ refers to the pair /o/-/a:/, /o/ refers to /o/-/o:/, and /u/ refers to /u/-/u:/. 


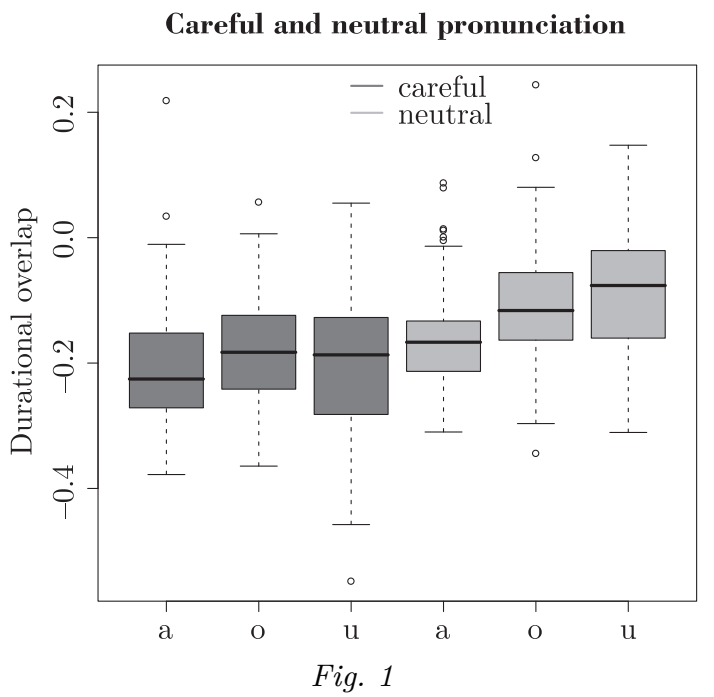

Durational overlap (DurOL) for vowels $/ \mathrm{a} /, / \mathrm{o} /, / \mathrm{u} /$ in careful and casual style

\subsubsection{Occupation and gender}

In view of the findings presented in 3.2.1, the following step in the analysis was performed separately for careful and neutral speech style. There was a tendency for employees to neutralise more than students in both careful and neutral pronunciation, but the difference did not reach significance for any measure or sample (Figures 2, 3).
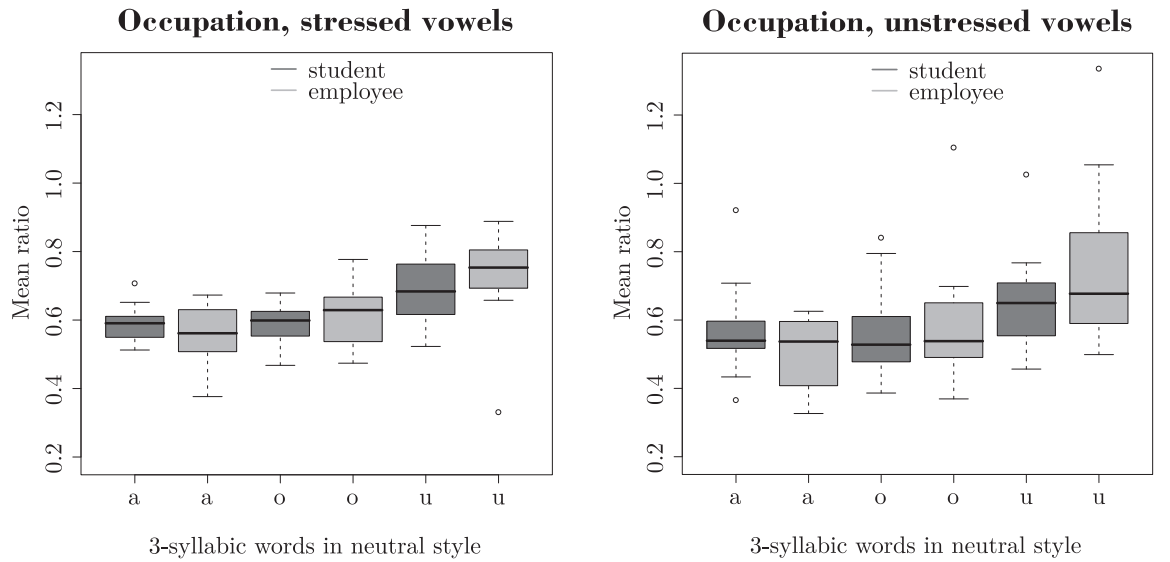

Fig. 2

Ratio of means (MeanR) for vowels /a/, /o/, /u/ according to occupation 

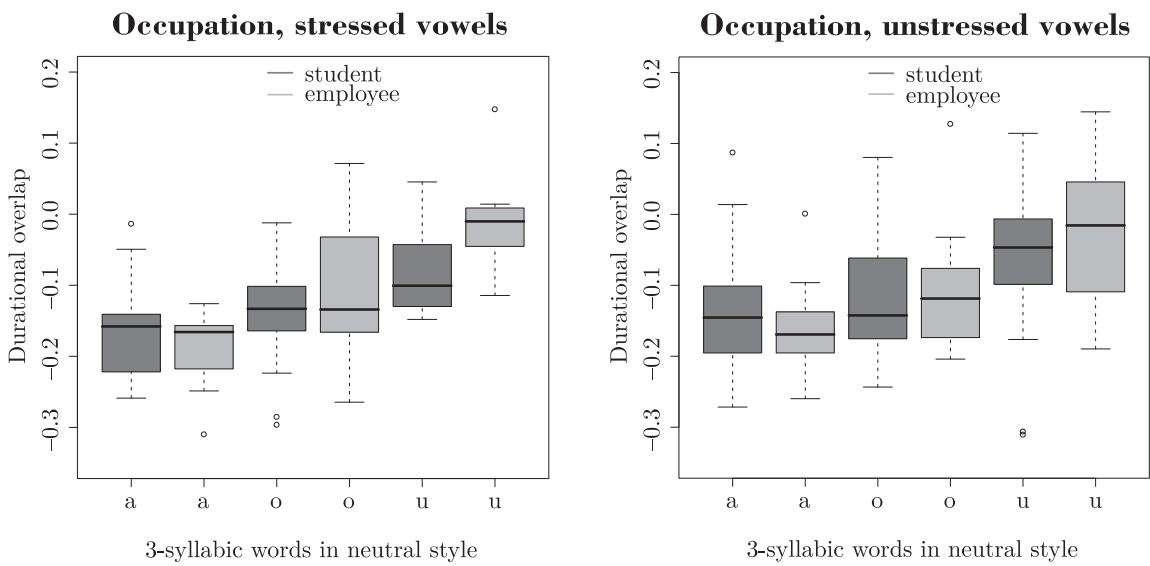

Fig. 3

Durational overlap (DurOL) for vowels $/ \mathrm{a} /, / \mathrm{o} / \mathrm{h} / \mathrm{u} /$ according to occupation

Gender did not have a significant effect on quantity distinction in either speech style (Figures 4, 5).
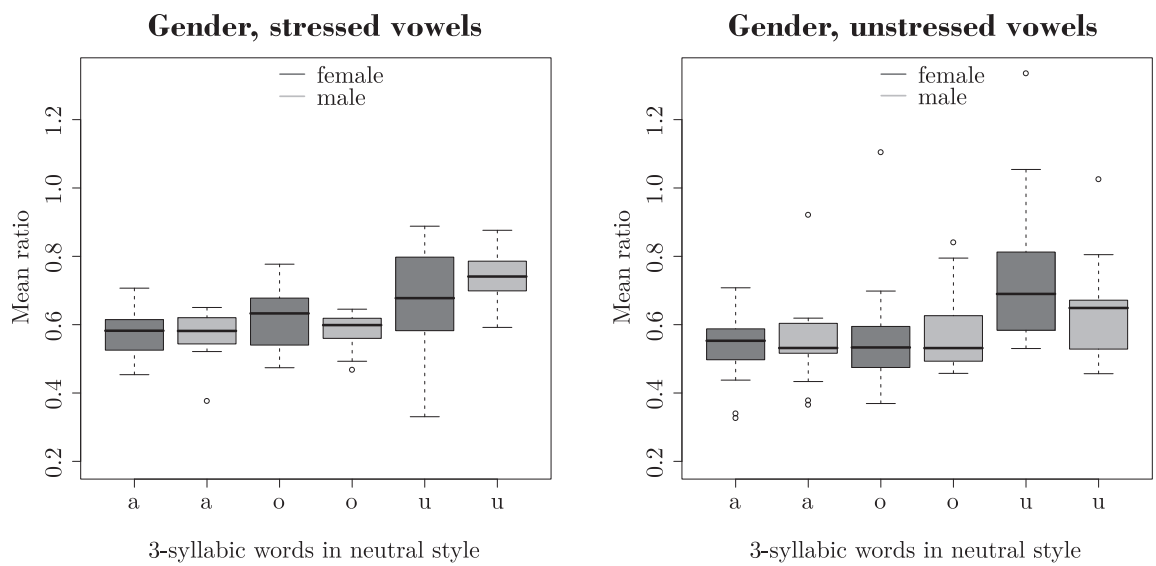

Fig. 4

Ratio of means (MeanR) for vowels $/ \mathrm{a} /, / \mathrm{o} /, / \mathrm{u} /$ according to gender

\subsubsection{Regional affiliation}

In the following step, the interaction of speech style and regional affiliation was tested for the three vowel categories. As described in 3.1.2, regional varieties were divided in three categories: Western Hungarian, Eastern Hungarian, and Budapest, of which the first category includes 

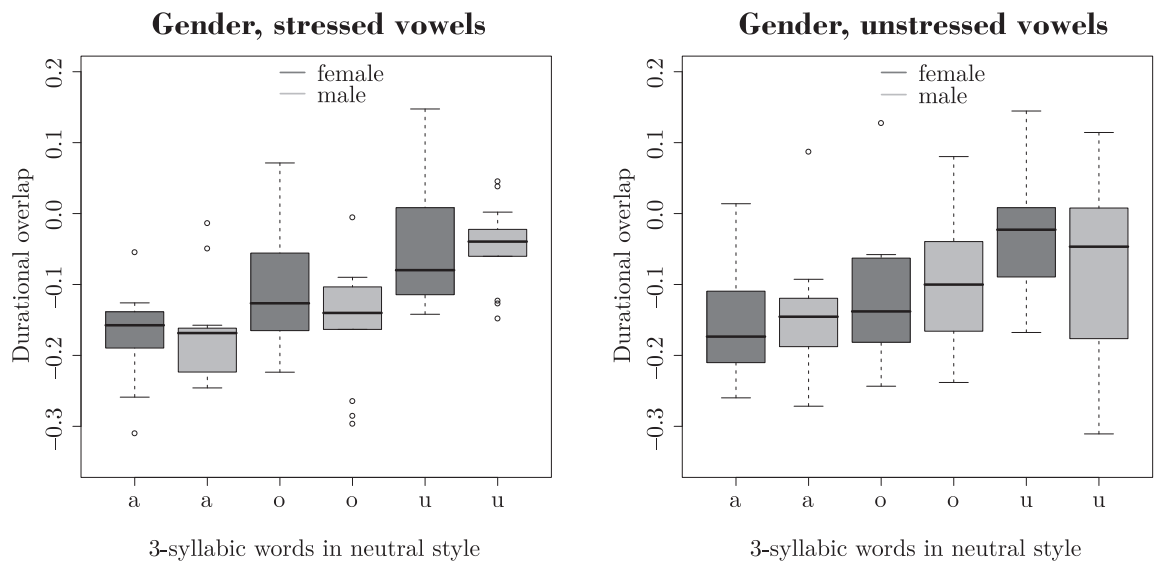

Fig. 5

Durational overlap (DurOL) for vowels $/ \mathrm{a} /, / \mathrm{o} /, / \mathrm{u} /$ according to gender

dialects with little or no quantity distinction for $/ \mathrm{u} /$, and the last is better described in sociolinguistic than in regional terms.

Speakers of Eastern Hungarian tended to maintain the quantity distinction in stressed syllables throughout all vowel categories, though no significant differences were found for MeanR or DurOL (Figure 6). However, they did not differ from other speakers with regard to neutralisation in unstressed syllables: they produced even more durational overlap for $/ \mathrm{u} /$ than other speakers did. There was a general tendency for Budapest speakers to neutralise quantity distinction in stressed /o/, both in careful and neutral style.
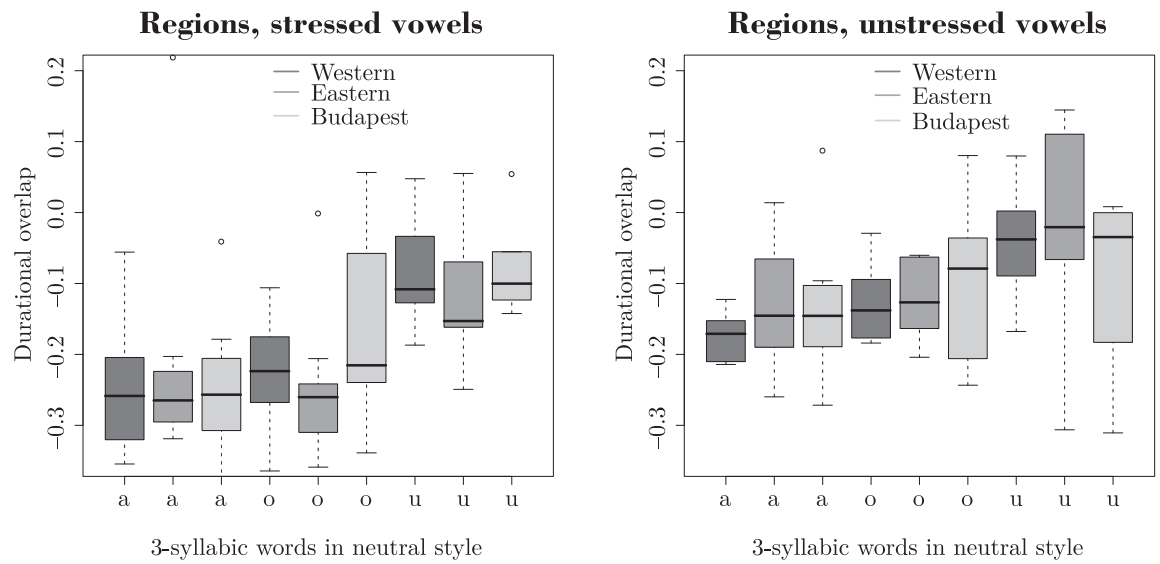

Fig. 6

Durational overlap (DurOL) for vowels /a/, /o/, /u/ according to regional affiliation

Acta Linguistica Hungarica 57, 2010 


\subsubsection{Social status}

The correlation between social status and quantity distinction was modelled by linear regression (Figures 7, 8, and 9). Stressed /u/ and unstressed /o/ had lowest indices for the lower social groups and those around group 6 .
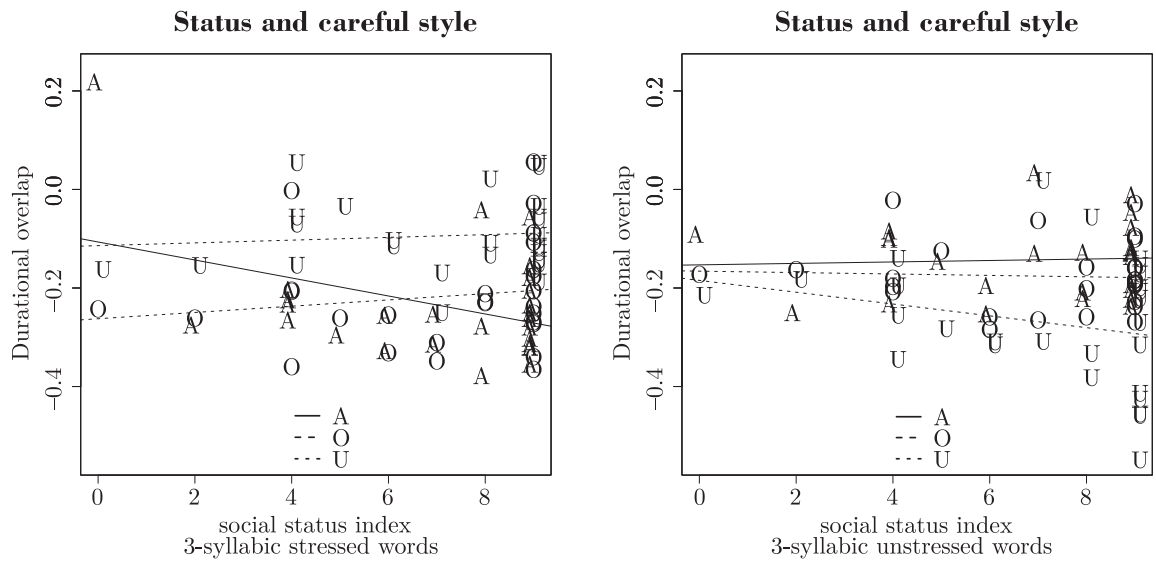

Fig. 7

Durational overlap (DurOL) for vowels /a/, /o/, /u/ in careful style, according to status, with linear regression
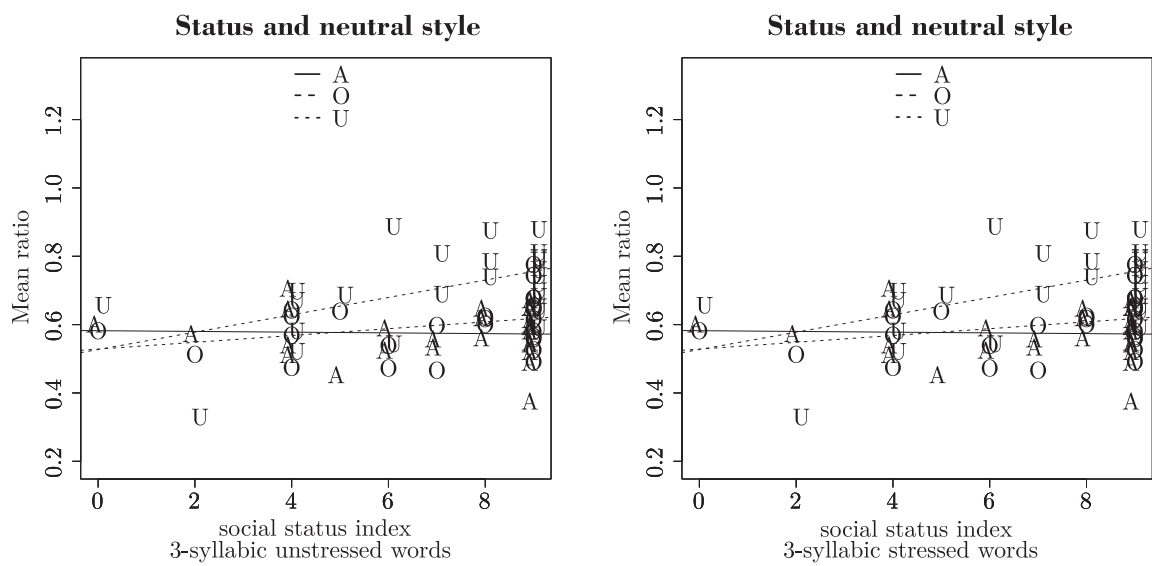

Fig. 8

Ratio of means (MeanR) for vowels /a/, /o/, /u/ in neutral style, according to status, with linear regression 

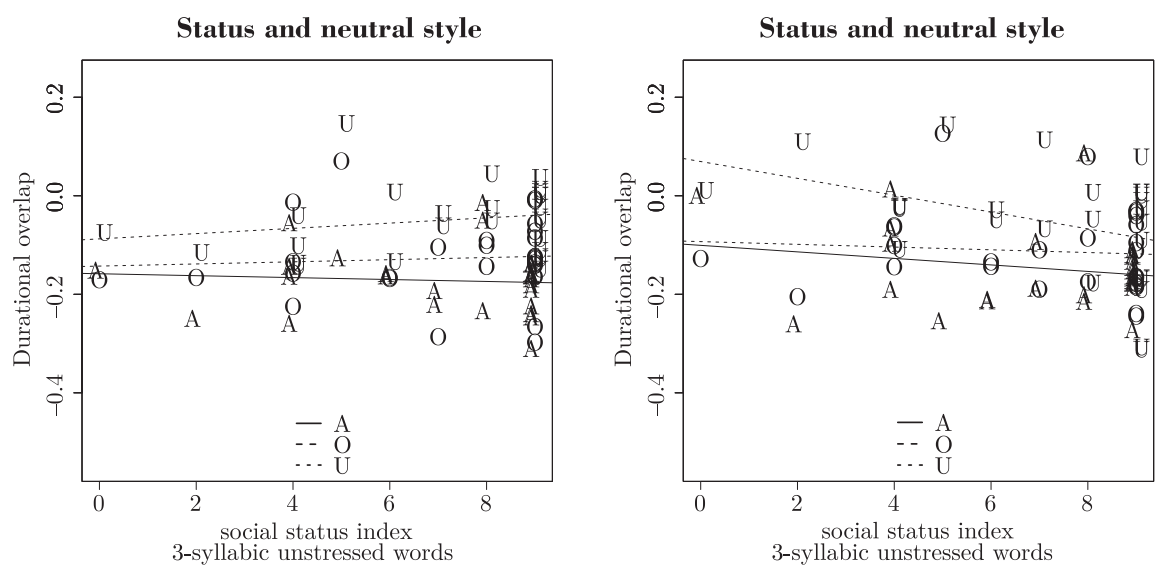

Fig. 9

Durational overlap (DurOL) for vowels /a/, /o/, /u/ in neutral style, according to status, with linear regression

Unstressed / $\mathrm{u}$ / was neutralised in nearly all status groups in neutral style, more obviously in terms of DurOL than MeanR (Figures 8, 9). The regression line was falling towards higher status groups, which can be interpreted as a bias towards less neutralisation in groups 8 and 7. (The falling tendency was maintained even if the high MeanR value for the only speaker in group 2 was ignored.) No clear tendency and a smaller amount of neutralisation were seen for unstressed /o/, and it was obviously not present for $/ \mathrm{a} /$.

Neutralisation of stressed / $\mathrm{u} /$ was less characteristic for lower status groups than for mid and higher ones. DurOL for stressed /o/ reached 0 for speakers in groups 4 and 5 . /a/ was typically the best distinguished vowel through all groups.

Even if the number of speakers in the groups is rather small (apart from group 9), the slope of the regression lines reveal very general tendencies in neutral style: lines for $/ \mathrm{u} /$ have higher absolute slopes (be it negative or positive) than those for $/ \mathrm{o} /$ and $/ \mathrm{a} /$. It is not obvious at first glance why regression tendencies have opposite directions for stressed and unstressed vowels. We will come back to this point in the Discussion.

\subsubsection{Attitude}

Positive, negative and neutral attitude towards careful pronunciation was analysed for stressed and unstressed syllables. The distinction of /a/ did 

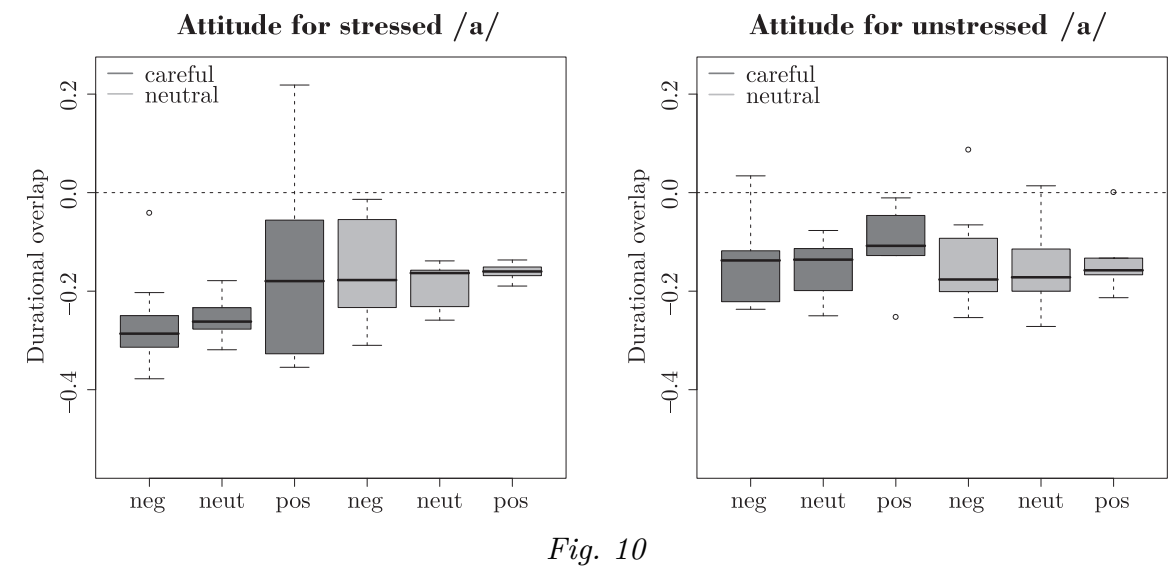

Fig. 10

Durational overlap (DurOL) for /a/ according to speakers' attitude towards careful pronunciation. The dotted line shows quantity neutralisation

not differ with regard to attitude in any speech style (Figure 10). All medians (MeanR and DurOL, careful and neutral style) were higher for stressed /o/ in the negative attitude group than in the positive one, although the differences were not significant due to large standard deviations (Figure 11). The same tendency was found for unstressed /u/, but not for unstressed /o/ and stressed / $\mathrm{u} /$ (Figure 12). It is important to note that both MeanR and DurOL showed a strong neutralisation tendency for stressed $/ \mathrm{u} /$, regardless of the speaker's attitude. The unexpectedly low amount of unstressed $/ \mathrm{u} /$ neutralisation in careful pronunciation is presumably a consequence of differences in the sentence structure: some speakers uttered the sentence with the carrier word vonatút with a weak boundary after the target syllable, while it was less frequently the case for the target kakadut 'cockatoo-acc'. Thus, the durational distinction might be enhanced by phrase-final lengthening of the long vowel.

\section{Discussion}

Although the unstable nature of vowel quantity distinction has seldom been described as a sound change phenomenon (with the exception of Magdics 1960), there are hints that we might be faced with a sound change process. The change obviously does not fit the criteria for change from above listed in Labov (1994), since quantity neutralisation is not prestigious and appears more rarely in careful speech style (as described in earlier papers and in the present study). 

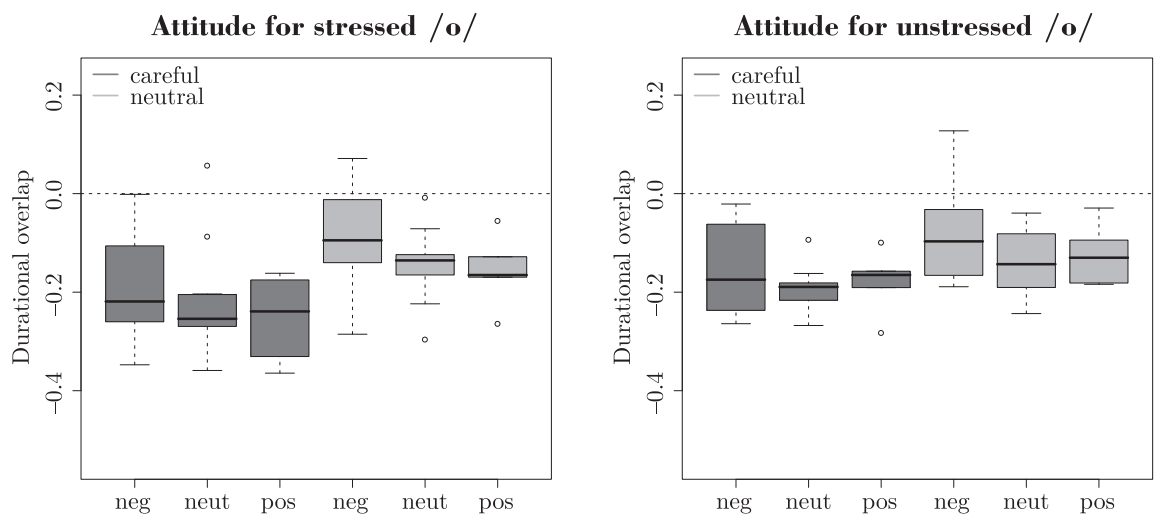

Fig. 11

Durational overlap (DurOL) for /o/ according to speakers' attitude towards careful pronunciation. The dotted line shows quantity neutralisation
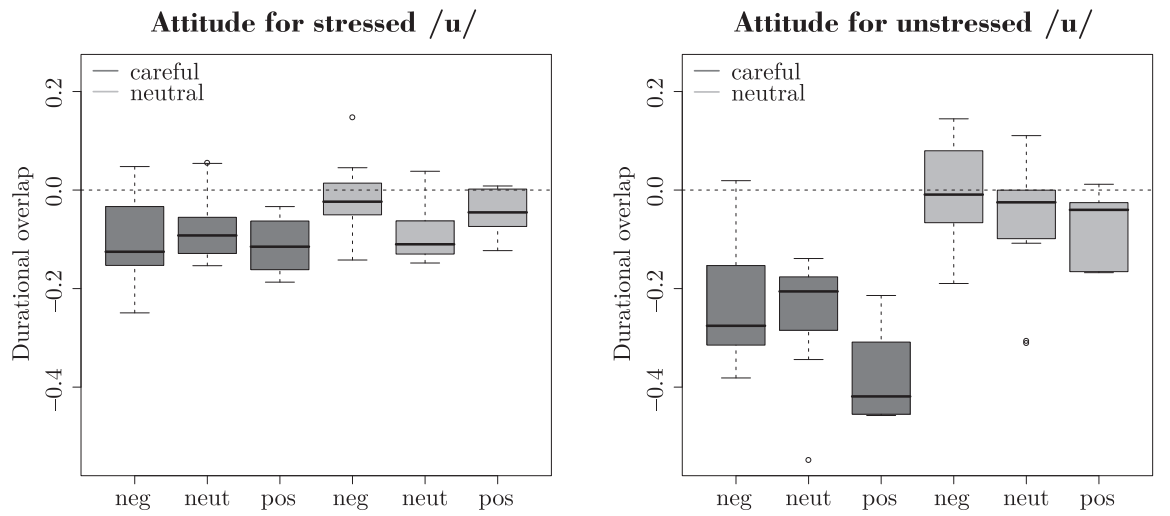

Fig. 12

Durational overlap (DurOL) for $/ \mathrm{u} /$ according to speakers' attitude towards careful pronunciation. The dotted line shows quantity neutralisation

In what follows, we will interpret our results along Labov's description provided for sound change from below.

Linguistic relevance: Changes of this kind are always characterised by internal linguistic factors. The poor functional load for high vowel quantity opposition is in line with this criterion: a feature with little relevance for the system is more likely to trigger a change than a frequently utilised feature. If the functional load of the quantity distinction is taken into account, it is not surprising that high vowels are more likely to be neutralised than mid or low ones. This is especially true for unstressed 
vowels which are generally shorter in Hungarian than stressed ones (as was shown in Mády et al. 2008). High vowels have short intrinsic durations, and they obviously cannot be shortened beyond a given point without information loss. As we argued in the Introduction, the quantity distinction could be substituted by the quality distinction as a primary feature, but this is not the case in Hungarian.

Vernacular: According to Labov, sound change from below appears first in colloquial speech. The predominance of neutralisation of unstressed high and partly mid vowels has been discussed by many authors (Magdics 1960; Kassai 1991; Siptár-Törkenczy 2000) and is a generally acknowledged phenomenon in phonological descriptions. As we have shown in this paper, neutralisation is not restricted to unstressed vowels in present days, but also applies to stressed high and partly to mid vowels in neutral — and less frequently also in careful — speech style.

Occupation and gender: Sound change from below is generally said to be introduced by younger speakers. This tendency was not observed in our data set. One possible reason is that the group of employees which had a mean age of less than 45 years included young adults who might use more neutralisation than adults of higher age. While females are often regarded as leaders in sound change processes, this was not found in our sample.

Status: Change from below is often led by speakers who rank around the midpoint of the social scale. In our study, neutralisation was more common in higher classes for stressed /u/, but less common for the unstressed vowel. It is important to note that the degree of neutralisation was generally higher in unstressed position. One possible explanation is that neutralisation for unstressed $/ \mathrm{u} /$ has become so widely accepted in colloquial speech that it has lost its status as a social marker and is on the way of becoming systematic within the vowel system, while neutralisation of stressed $/ \mathrm{u} /$ might still participate in an ongoing sound change process.

The stronger neutralisation tendency for stressed /u/ in higher classes does not necessarily contradict the assumption that neutralisation indeed might be seen as change from below, as an observation during the experiments show. Speakers from the lowest classes found the reading task in neutral style rather challenging because of the relatively long sentences. A comparison of Figures 7, 8, and 9 show that speaking style has a small effect on the speakers in groups 0 and 2 , while speakers with higher scores use less neutralisation in careful than in neutral style. This 
again supports the hypothesis that durational distinction of stressed /u/ is used as a social marker by speakers.

Consciousness: Sound change from below is based on a linguistic marker that speakers are unaware of, at least at the first stage. Even if our methodology is not suitable to investigate to what extent speakers are conscious of neutralisation, there is evidence that they use quantity distinction for attitude marking in some but not other vowel categories. The rather stable durational distinction for /a/ is maintained by all attitude groups, while a larger overlap and variability characterise the production of $/ \mathrm{o} /$ and $/ \mathrm{u} /$ for speakers with negative attitude against careful pronunciation.

The aim of the present pilot study was to investigate general tendencies of vowel quantity neutralisation in Hungarian. We found evidence that (1) neutralisation is stronger in high than in low vowels, with mid vowels showing an intermediate behaviour, and that (2) neutralisation is also present in stressed syllables with high and mid vowels. Differences with regard to style, status, and attitude for / $\mathrm{u} /$ and partly for /o/ signal that social factors do play a role in quantity neutralisation. Further investigation has to clarify whether some status groups use neutralisation more often than others, and whether there is an age-based difference that could not be uncovered in the present study.

\section{References}

Abercrombie, David 1967. Elements of general phonetics. Edinburgh University Press, Edinburgh.

Harrington, Jonathan - Felicitas Kleber - Ulrich Reubold 2008. Compensation for coarticulation, /u/-fronting, and sound change in Standard Southern British: An acoustic and perceptual study. In: Journal of the Acoustical Society of America $123: 2825-35$.

Kálmán, Béla 1989. Nyelvjárásaink. 5. kiadás [Hungarian dialects. Fifth edition]. Tankönyvkiadó, Budapest.

Kassai, Ilona 1991. Hol tart a magyar magánhangzók időtartamának ingadozása? [On the durational variation of Hungarian vowels]. In: Magyar Nyelvőr 115 : 69-80.

Kovács, Magdolna 2002. Tendenciák és szabályszerüségek a magánhangzó-időtartamok produkciójában és percepciójában [Tendencies and regularities in the production and perception of vowel duration]. Doctoral dissertation, Debreceni Egyetem.

Labov, William 1994. Principles of linguistic change: Internal factors. Wiley-Blackwell, Oxford. 
Laver, John - Peter Trudgill 1979. Phonetic and linguistic markers in speech. In: Klaus R. Scherer-Howard Giles (eds): Social markers in speech, 1-32. Cambridge University Press, Cambridge.

Mády, Katalin 2008. Magyar magánhangzók vizsgálata elektromágneses artikulográffal gyors és lassú beszédben [Investigation of Hungarian vowels in normal and fast speech: An articulography study]. In: Mária Gósy (ed.): Beszédkutatás 2008 [Speech research 2008], 52-66. MTA Nyelvtudományi Intézet, Kempelen Farkas Beszédkutató Laboratórium, Budapest.

Mády, Katalin - Lasse Bombien - Uwe D. Reichel 2008. Is Hungarian losing the vowel quantity distinction? In: Proceedings of the 8th International Seminar on Speech Production, 445-8. INRIA, Strasbourg.

Mády, Katalin-Uwe D. Reichel 2007. Quantity distinction in the Hungarian vowel system - Just theory or also reality? In: Proceedings of the 16th International Congress of Phonetic Sciences, 1053-6. Saarbrücken.

Magdics, Klára 1960. A szóvégi magánhangzók rövidülése a köznyelvben [Word-final vowel shortening in colloquial Hungarian]. In: Nyelvtudományi Közlemények 62 : 301-24.

Magdics, Klára 1965. A magyar beszédhangok akusztikai szerkezete [Acoustic structure of Hungarian speech sounds] (Nyelvtudományi Értekezések 49). Akadémiai Kiadó, Budapest.

Magdics, Klára 1966. A magyar beszédhangok időtartama [Duration of Hungarian speech sounds]. In: Nyelvtudományi Közlemények 68:125-39.

Milroy, Lesley-Matthew Gordon 2003. Sociolinguistics: Method and interpretation. Blackwell, Malden MA \& Oxford.

Podlipský, Václav Jonáš - Radek Skarnitzl - Jan Volín 2009. High front vowels in Czech: A contrast in quantity or quality? In: Proceedings of the Interspeech Conference, Brighton, 132-5. ISCA, Brighton.

Siptár, Péter - Miklós Törkenczy 2000. The phonology of Hungarian. Oxford University Press, Oxford. 